\title{
Different Profiles of Antibodies and Cytokines Were Found Between Severe and Moderate COVID-19 Patients
}

\section{OPEN ACCESS}

Edited by:

Vishwanath Venketaraman,

Western University of Health Sciences,

United States

Reviewed by:

Balaji Banoth,

St. Jude Children's Research Hospital,

United States

Jeffrey R. Schneider,

Rush University, United States

*Correspondence:

Yongjian Liu

yongiian325@sina.com

Lin Li

dearwood@sina.com

${ }^{t}$ These authors have contributed equally to this work and

share first authorship

Specialty section:

This article was submitted to

Viral Immunology,

a section of the journal

Frontiers in Immunology

Received: 11 June 2021 Accepted: 03 August 2021

Published: 19 August 2021

Citation:

Guo $Y, L i T$, Xia $X$, SU B, Li H, Feng $Y$, Han J, Wang X, Jia L, Bao Z, Li J, Liu Y and Li L (2021) Different Profiles of Antibodies and Cytokines Were Found

Between Severe and Moderate COVID-19 Patients.

Front. Immunol. 12:723585. doi: 10.3389/fimmu.2021.723585
Yaolin Guo ${ }^{1 \dagger}$, Tianyi $\mathrm{Li}^{1+}$, Xinyi Xia ${ }^{2 \dagger}$, Bin $\mathrm{Su}^{3}$, Hanping $\mathrm{Li}^{1}$, Yingmei Feng ${ }^{3}$, Jingwan Han ${ }^{1}$, Xiaolin Wang ${ }^{1}$, Lei Jia ${ }^{1}$, Zuoyi Bao ${ }^{1}$, Jingyun $\mathrm{Li}^{1}$, Yongjian $\mathrm{Liu}^{1 *}$ and $\mathrm{Lin}_{\mathrm{Li}}{ }^{1 *}$

${ }^{1}$ Department of AIDS Research, State Key Laboratory of Pathogen and Biosecurity, Beijing Institute of Microbiology and Epidemiology, Beijing, China, 2 Institute of Laboratory Medicine, Jinling Hospital, Naniing University School of Medicine,

The First School of Clinical Medicine, Southern Medical University, Nanjing, China, ${ }^{3}$ Beijing Youan Hospital, Capital Medical University, Beijing, China

Objectives: Our objective was to determine the antibody and cytokine profiles in different COVID-19 patients.

Methods: COVID-19 patients with different clinical classifications were enrolled in this study. The level of IgG antibodies, IgA, IgM, IgE, and IgG subclasses targeting $N$ and $S$ proteins were tested using ELISA. Neutralizing antibody titers were determined by using a toxin neutralization assay (TNA) with live SARS-CoV-2. The concentrations of 8 cytokines, including IL-2, IL-4, IL-6, IL-10, CCL2, CXCL10, IFN- $\gamma$, and TNF- $\alpha$, were measured using the Protein Sample Ella-Simple ELISA system. The differences in antibodies and cytokines between severe and moderate patients were compared by t-tests or Mann-Whitney tests.

Results: A total of 79 COVID-19 patients, including 49 moderate patients and 30 severe patients, were enrolled. Compared with those in moderate patients, neutralizing antibody and IgG-S antibody titers in severe patients were significantly higher. The concentration of IgG-N antibody was significantly higher than that of IgG-S antibody in COVID-19 patients. There was a significant difference in the distribution of IgG subclass antibodies between moderate patients and severe patients. The positive ratio of anti-S protein lgG3 is significantly more than anti-N protein lgG3, while the anti-S protein IgG4 positive rate is significantly less than the antiN protein IgG4 positive rate. IL-2 was lower in COVID-19 patients than in healthy individuals, while IL-4, IL-6, CCL2, IFN- $\gamma$, and TNF- $\alpha$ were higher in COVID-19 patients than in healthy individuals. IL-6 was significantly higher in severe patients than in moderate patients. The antibody level of anti-S protein was positively correlated with the titer of neutralizing antibody, but there was no relationship between cytokines and neutralizing antibody.

Conclusions: Our findings show the severe COVID-19 patients' antibody levels were stronger than those of moderate patients, and a cytokine storm is associated with COVID19 severity. There was a difference in immunoglobulin type between anti-S protein antibodies and anti-N protein antibodies in COVID-19 patients. And clarified the value of the profile in critical prevention.

Keywords: SARS-CoV-2, COVID-19, neutralizing antibody, immunoglobulin type, cytokine 


\section{INTRODUCTION}

Severe acute respiratory syndrome coronavirus 2 (SARS-CoV-2) has spread worldwide for more than a year. As of March 2021, SARS-CoV-2 has infected more than 100 million people worldwide, resulting in more than 2 million deaths, and the global epidemic situation of SARS-CoV-2 remains serious. Individuals infected by SARS-CoV-2 have different clinical symptoms. Most individuals have moderate symptoms, such as fever, respiratory tract symptoms, and imaging features of pneumonia. Approximately $14 \%$ of people have severe symptoms (1), such as respiratory distress and respiratory rate $\geq 30$ times/min, mean oxygen saturation $\leq 93 \%$ at resting-state, or arterial blood oxygen partial pressure $(\mathrm{PaO} 2)$ /oxygen concentration $(\mathrm{FiO} 2) \leq 300 \mathrm{mmHg}$ $(1 \mathrm{mmHg}=0.133 \mathrm{kPa})$ and progressive aggravation of clinical symptoms. Considering that the case-fatality rate of critical COVID-19 patients is as high as $2.3 \%(1-3)$, it is important to clarify the internal mechanism of severe illness.

Antibodies, especially neutralizing antibodies, are associated with the severity of the patient $(4,5)$. According to the difference of serum antibody content, the evaluation of antibody level mainly focused on the titer of IgA, IgM and IgG. Most individuals diagnosed with SARS-CoV-2 infection by PCR will produce IgA, $\operatorname{IgM}$, and IgG against the spike protein (S) and nucleocapsid protein (N) within 1-2 weeks of symptoms, and remain elevated following initial viral clearance (6-11). Previous studies ignored that the highest content of IgG in serum has four different functional subclasses, only one study on IgG subtypes has been reported (12). IgE is extremely scarce, but IgE is related to hypersensitivity, which has been less studied in SARS-CoV-2 (13). Also, neutralizing antibodies (nAbs) can bind to viral particles and prevent them from entering host cells, and provide specific immune defense for infected patients. Thus, the level of neutralizing antibodies can be used to judge the ability of the body to resist the virus. Researchers have already shown that neutralizing antibodies that can block virus infection have a good therapeutic effect on patients with COVID-19 (14-19). There is evidence that neutralizing antibodies to SARS$\mathrm{CoV}-2$ infection persist for months, and a higher titer of nAbs, IgG, and $\operatorname{IgM}$ is independently associated with a worse clinical classification (20-25).

Aggressive inflammatory response and the release of a large amount of pro-inflammatory cytokines, or cytokine storm has been reported to be involved in COVID-19 severe pathogenesis $(26,27)$. IL-2 can stimulate the proliferation of NK cells and secrete a variety of cytokines, increase the cytotoxicity $(28,29)$. IL- 4 can specifically induce Th2 cells and stimulate the proliferation of activated B cells and T cells (30-33). IL-6 is a major highly inducible pro-inflammatory cytokine, induces IL-8 and MCP-1 secrete, increases vascular permeability during the early phase of inflammation (34-36). IL-10 is a key antiinflammatory mediator ensuring protection of a host from over-exuberant responses to pathogens and microbiota (37-39). CCL2 and CXCL10 are chemokines, CCL2 facilitates the migration and infiltration of monocytes/macrophages to sites of inflammation produced by either tissue injury or infection, CXCL10 could drive longer duration of mechanical ventilation during COVID-19 ARDS (40-42). TNF-a and IFN- $\gamma$ mediated inflammatory cell death signaling pathways to limiting tissue damage in COVID-19 patients (43). An increasing amount of clinical data suggests that a cytokine storm is associated with COVID-19 severity and is also a crucial cause of death from COVID-19, including IL-2, IL-6, IL-7, IL-10, G-CSF, IP-10, MCP-1, MIP-1 $\alpha$, and TNF- $\alpha$ (44-49).

However, the number of cases in previous studies is small, and no comprehensive and systematic study has been performed. In this study, we intend to collect a cross-sectional sample of moderate and severe patients to systematically analyze the distribution of anti-N protein and anti-S protein IgA, IgM, IgE, IgG1, IgG2, IgG3, and IgG4 and the relationship among IgG antibody against spike protein (IgG-S), nucleoprotein (IgG-N), nAbs and 8 cytokines (IL-2, IL-4, IL-6, IL-10, CCL2, CXCL10, IFN- $\gamma$, and TNF- $\alpha$ ). The immunological differences between moderate and severe patients were compared to clarify the value of the profile in critical prevention.

\section{METHODS}

\section{Patients and Data Sources}

This study included 79 patients with COVID-19 and 10 healthy controls. According to the Chinese Government Diagnosis and Treatment Guideline ( $8^{\text {th }}$ edition), the clinical classification was divided into moderate patients and severe patients. To inactivate the serum and plasma sample complement, all samples were incubated in a water bath at $56^{\circ} \mathrm{C}$ for 30 minutes.

\section{IgG Antibody of Spike Protein and Nucleoprotein Measurement}

In our study, the materials for indirect chemical luminescence analysis (CLIA) to measure IgG antibodies against SARS-CoV-2 spike protein and nucleoprotein were provided by Beijing KEWEI Clinical Diagnostic Reagent Inc. Unlike traditional enzyme-linked reaction kits, the CLIA method can quickly and effectively quantify antibody content. To detect IgG, $100 \mu \mathrm{L}$ of sample diluent was added to each 96-well plate, and $10 \mu \mathrm{L}$ of serum, plasma or standard S0-S6 was added to the corresponding well and incubated at $37^{\circ} \mathrm{C}$ for 15 minutes. We then washed the plate five times with $300 \mu \mathrm{L}$ of wash buffer. Then, $100 \mu \mathrm{L}$ conjugate dilution was added to each well and incubated at $37^{\circ} \mathrm{C}$ for 15 minutes. After the second wash cycle, $50 \mu \mathrm{L}$ glowing substrates A and $50 \mu \mathrm{L}$ glowing substrates B were added. After mixing, the solution was incubated in the dark at room temperature for 1-5 minutes. Then, the plate was placed on an ELISA reader to acquire a relative light unit (RLU). The specific content of the specimen IgG antibody can be calculated by the standard curve from the standard S0-S6.

\section{Toxin Neutralization Assay (TNA) With Live SARS-CoV-2}

The neutralization titer was determined in Vero E6 cells, and the live strain SARS-CoV-2 (BetaCoV/Beijing/AMMS01/2020) used in the neutralization assay was isolated from a throat swab of a COVID-19 patient (50). To achieve $90-95 \%$ confluence of Vero E6 cells, a 96-well plate with $1 \times 10^{4}$ Vero E6 cells per well was incubated at $37^{\circ} \mathrm{C}$ and $5 \% \mathrm{CO}_{2}$ one day in advance. The live strain SARS-CoV-2 of $120 \mathrm{TCID}_{50}$ was mixed with inactivated 
serum and plasma that had been serially diluted 2 -fold, from 1:10 to $1: 1280$, and incubated for $1 \mathrm{~h}$ at $37^{\circ} \mathrm{C}$ and $5 \% \mathrm{CO}_{2}$. Each concentration had two repetitions. Then, the mixture was added to 96 -well plates of Vero cells and cultivated at $37^{\circ} \mathrm{C}$ and $5 \% \mathrm{CO}_{2}$ with daily microscopic examination for cytopathic effects (CPEs). On day 3, the titers of antibody were calculated as the reciprocal of the highest dilution at which the CPE was completely inhibited on the well (51). If no neutralization reaction was observed in the patient sample at the initial dilution concentration of $1: 10$, we regarded the neutralization antibody titer as 0 .

\section{Typing of Anti-S Protein and Anti-N Protein Antibodies}

ELISA plates, coated with the SARS-CoV-2 N protein or $\mathrm{S}$ protein in advance, were used to detect the classification of immunoglobulins in moderate patients and severe patients. First, $100 \mu \mathrm{L}$ sample diluent was added to each well, and $10 \mu \mathrm{L} \mathrm{1:20}$ diluted serum and plasma or standard from the kit was added to the corresponding well and incubated at $37^{\circ} \mathrm{C}$ for 60 minutes. Then, the plate was washed five times with $300 \mu \mathrm{L}$ of wash buffer. One of seven antibodies (including HRPmonoclonal mouse anti-human IgG1, IgG2, IgG3, IgG4, IgA, IgM, and IgE) diluted $1: 1000$ was added to $100 \mu \mathrm{L}$ in each well and incubated at $37^{\circ} \mathrm{C}$ for 30 minutes. After the second wash cycle, $50 \mu \mathrm{L}$ glowing substrate $\mathrm{A}$ and $50 \mu \mathrm{L}$ glowing substrate $\mathrm{B}$ were added. After incubating for 15 minutes in the dark, $50 \mu \mathrm{L}$ stop solution was added to each well. Then, the plate was placed on an ELISA reader to detect the absorbance at $450 \mathrm{~nm}$ and 630 $\mathrm{nm}$. The cutoff value was calculated, and samples with a fluorescence value greater than 0.2 were regarded as positive; otherwise, they were regarded as negative.

\section{Cytokine Measurement}

The concentrations of 8 cytokines, including IL-2, IL-4, IL-6, IL-10, CCL2, CXCL10, IFN- $\gamma$, and TNF- $\alpha$, were measured using the Protein Sample Ella-Simple ELISA system (Revision 1.1, Mar 2020) following the manufacturer's instructions. The sera of healthy individuals $(n=10)$ were included as controls.

\section{Statistical Analysis}

All continuous variable descriptions are described as medians (IQRs), and categorical characteristics are described as numbers (\%). Means for continuous variables were compared using independent group t-tests when the data were normally distributed; otherwise, the Mann-Whitney test was used. All statistical analyses were performed using SPSS (Statistical Package for the Social Sciences) version 21.0 software (SPSS Inc), and a $P$-value $<0.05$ was considered statistically significant.

\section{RESULTS}

\section{Demographic Characteristics}

The demographic characteristics of these patients are summarized in Table 1. This study included 49 moderate patients and 30 severe
TABLE 1 | Baseline characteristics of patients infected with COVID-19.

\begin{tabular}{|c|c|c|c|}
\hline Characteristic & $\begin{array}{l}\text { Moderate Patients } \\
\qquad(\mathrm{n}=49)\end{array}$ & $\begin{array}{l}\text { Severe Patients } \\
\qquad(n=30)\end{array}$ & $\begin{array}{c}\text { Total } \\
(\mathrm{n}=79)\end{array}$ \\
\hline \multicolumn{4}{|l|}{ Sex } \\
\hline Female & 30 & 15 & 45 \\
\hline Male & 19 & 15 & 34 \\
\hline \multicolumn{4}{|l|}{ Age, y } \\
\hline 35-39 & 2 & 2 & 4 \\
\hline $40-49$ & 3 & 0 & 3 \\
\hline $50-59$ & 10 & 6 & 16 \\
\hline $60-69$ & 20 & 16 & 36 \\
\hline $70-79$ & 11 & 4 & 15 \\
\hline $80-89$ & 3 & 2 & 5 \\
\hline Median (IQR) & 63.6 & 63 & $\begin{array}{c}63.4 \\
(58-69)\end{array}$ \\
\hline \multicolumn{4}{|l|}{ Weeks after PCR positivity } \\
\hline 1 & 6 & 3 & 9 \\
\hline 2 & 11 & 4 & 15 \\
\hline 3 & 2 & 7 & 9 \\
\hline 4 & 14 & 5 & 19 \\
\hline 5 & 12 & 8 & 20 \\
\hline 6 & 3 & 1 & 4 \\
\hline 7 & 1 & 2 & 3 \\
\hline \multicolumn{4}{|l|}{ Comorbidities } \\
\hline Hypertension & 13 & 8 & 21 \\
\hline Diabetes & 11 & 6 & 17 \\
\hline Heart-related disease & 7 & 2 & 9 \\
\hline
\end{tabular}

patients. There were 45 females and 34 males among a total of 79 COVID-19 patients. The median age of the study's patients was 63.4 years, and $70.89 \%$ of patients were more than 60 years old. We enumerated the PCR positive detection time of moderate patients and severe patients, and found that there was no difference in PCR positive detection time between the two groups by the MannWhitney test. Average ages of moderate and severe patients were similar, at 63.6 and 63, respectively. Of all enrolled patients, 59.49\% had complications. Among the 47 patients with complications, hypertension, diabetes, and heart-related disease accounted for the largest proportion, at $44.68 \%, 36.17 \%$, and $19.15 \%$, respectively. Moreover, patients with a history of disease accounted for $65.96 \%$ and $34.04 \%$ of moderate and severe patients, respectively.

\section{Neutralizing Antibody Titers in Moderate and Severe COVID-19 Patients}

A total of 79 serum and plasma samples in all groups of patients were analyzed for the titers of neutralizing antibodies with TNA. The clinical laboratory ELISA setup results in discrete titers of 0 , $20,40,80,160,320$, or 640 . The neutralizing antibody titer in severe patients was significantly higher than that in moderate patients, with geometric mean reciprocal titers of 79.59 and 164.4, respectively (Figure 1A, $P=0.039$ ). According to the study described by Wajnberg et al. (52), titers of $20,40,80$, and 160 were categorized as low titers, 320 as moderate, and 640 as high titers. For plasma therapy, titers of 320 or higher were initially deemed eligible. Of the 49 moderate patients, $10(20.41 \%)$ had a titer of $0,3(6.12 \%)$ of $20,12(24.49 \%)$ of 40,10 (20.41\%) of 80,12 $(24.49 \%)$ of 160 , and $2(4.08 \%)$ of 320 (Figure 1B). Of the 30 severe patients, $2(6.67 \%)$ of $20,7(23.33 \%)$ of $40,7(23.33 \%)$ of $80,6(20 \%)$ of $160,5(16.67 \%)$ of 320 , and $3(10 \%)$ of 640 
(Figure 1C). Thus, the vast majority of patients (87.34. \%) with COVID-19 have neutralizing antibodies. However, only a small number of patients $(12.66 \%)$ reached a qualified plasma therapeutic titer greater than or equal to 320 .

\section{IgG-N and IgG-S Antibody Levels in Moderate and Severe COVID-19 Patients}

We quantitatively detected IgG antibody concentrations of IgG-S and IgG-N to explore the two major antibodies in patients with COVID-19 against SARS-CoV-2. Figure 2 shows the comparison of spike protein and nucleoprotein IgG in the moderate $(n=49)$ and severe $(n=30)$ groups. The median values of IgG-S concentration in severe patients $(22748 \mathrm{ng} / \mathrm{mL})$ were significantly higher than in moderate patients $(14403 \mathrm{ng} / \mathrm{mL}$, $P<0.05)$. Moderate patients with IgG-S below the median had shorter PCR positivity time than those with IgG-S above the median $(P<0.05)$. The positivity time of PCR in severe patients with IgG-S lower than the median was shorter than that with higher median $(P<0.01)$. IgG-N in severe patients was significantly higher than in moderate patients, with median values of $380249 \mathrm{ng} / \mathrm{mL}$ and $191578 \mathrm{ng} / \mathrm{mL}$, respectively $(P<0.05)$. There was no difference in PCR positivity time between moderate and severe patients when IgG-N was below or above the median $(P>0.05)$. The median values of IgG-N concentration were 13.30 times higher than IgG-S in moderate patients and 16.72 times higher than IgG-S in severe patients $(\mathrm{P}<0.0001)$. We stratified moderate and severe COVID-19 patients by PCR positive detection time, and the difference of IgG-S and IgG-N concentrations is shown in Figure $\mathbf{S 1}$.

\section{Relationship Between IgG-N, IgG-S, and Neutralizing Antibodies}

Correlation analysis suggested that the IgG-S antibody concentration increased with increasing neutralizing antibody titer in both moderate and severe patients (Figure 3). Analysis showed that there was a positive correlation between IgG-S antibodies and neutralizing antibodies in moderate and severe COVID-19 patients $(P<0.05)$, and the regression equations were $\mathrm{Y}=0.0002665^{\star} \mathrm{X}+0.00357$ and $\mathrm{Y}=0.0001065^{\star}$ $\mathrm{X}+0.02778$, respectively.

\section{Classification of Anti-S Protein and Anti-N Protein Antibodies}

In moderate and severe COVID-19 patients, the positive ratio of anti-N protein antibodies was $\operatorname{Ig} A \geq \operatorname{IgM}>\operatorname{IgG}$, and the positive ratio of anti-S protein antibodies was $\operatorname{IgG} \geq \operatorname{IgA}>\operatorname{IgM}$ (Figure 4).
A

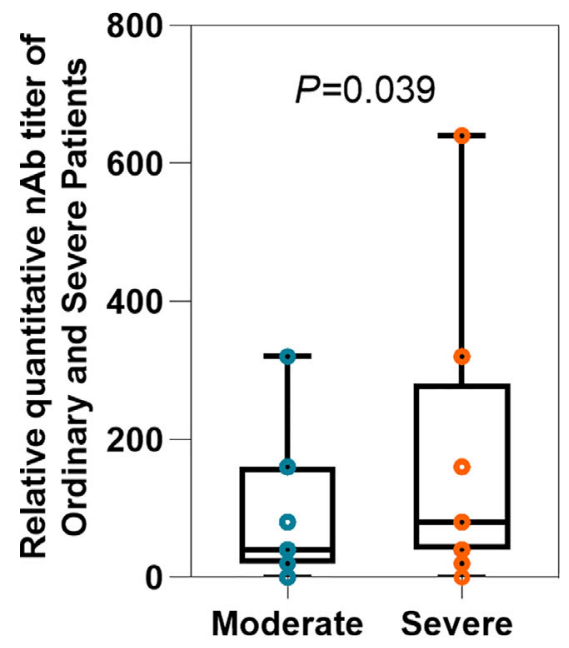

B

\section{Relative quantitative $n A b$ titer of Moderate Patients}

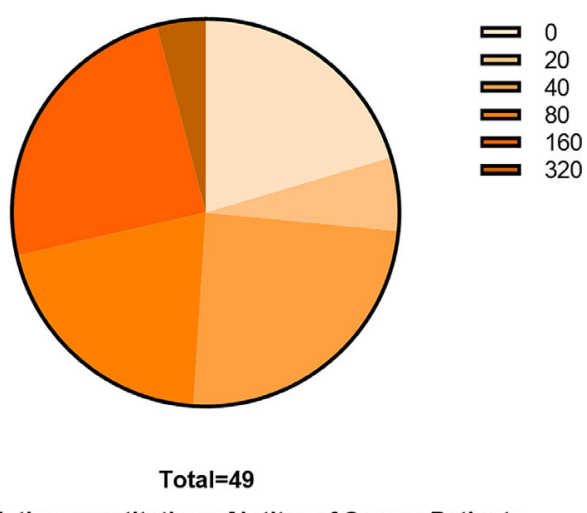

C Relative quantitative nAb titer of Severe Patients

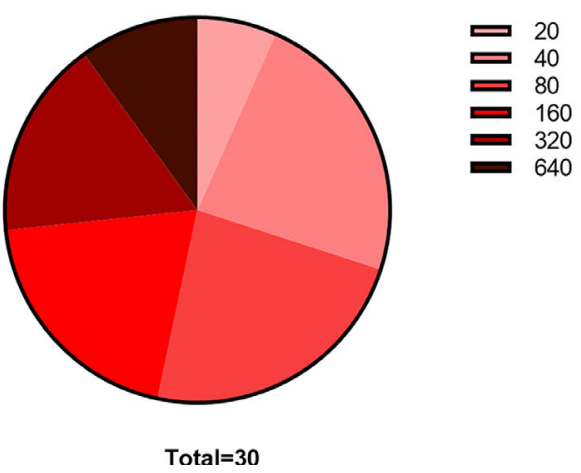

FIGURE 1 Comparison of relative quantitative $n A b$ titers between the moderate and severe groups. (A) Average titers of neutralizing antibodies in moderate ( $n=49)$ and severe $(n=30)$ patients. The box plots show the medians (middle line) and first and third quartiles (boxes), and the whiskers show the minimum and maximum. T-test $P$-values are depicted in the plots. $(\mathbf{B}, \mathbf{C})$ The percentage of moderate and severe patients with neutralizing antibody titers. 


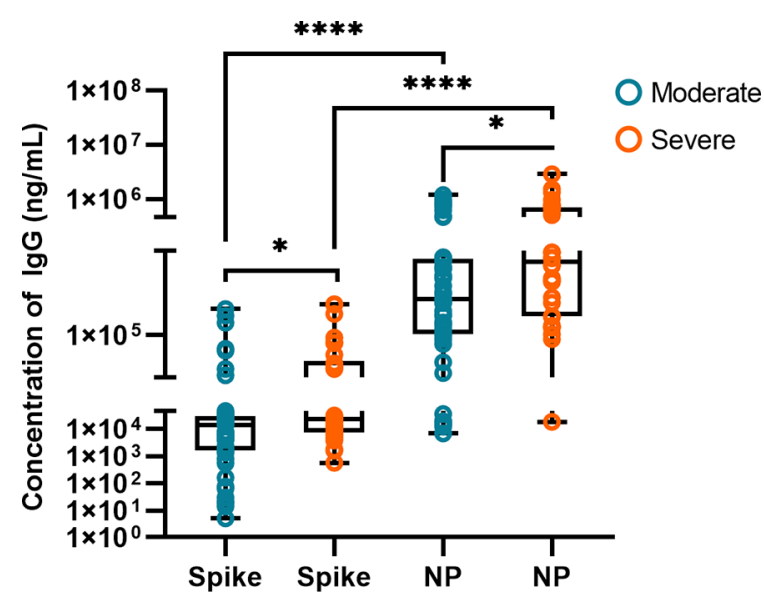

FIGURE 2 | Comparison of lgG-S and lgG-N antibodies in the moderate $(n=49)$ and severe $(n=30)$ groups. The box plots show the medians (middle line) and first and third quartiles (boxes), and the whiskers show the minimum and maximum. Mann-Whitney test $P$-values are depicted in the plots. ${ }^{\star} p<0.05,{ }^{* \star \star *} p<0.0001$

IgA of anti-S protein and anti-N protein was positive in severe patients, while the detection time of IgA-S and IgA-N negative was shorter than that of PCR positive in moderate patients $(P<0.05)$. IgM of anti-N protein was positive in all severe patients, but IgM of anti-S protein was negative in only two severe patients. Only the detection time of IgM-N negative was shorter than that of PCR positive in moderate patients $(P<0.05)$. Almost no positive IgE was detected.

IgG1 is the most abundant IgG subclass of anti-N protein and anti-S protein antibodies, while IgG2 is the least abundant IgG subclass. The positive ratio of anti-S protein IgG3 was significantly higher than that of anti-N protein IgG3, while the anti-S protein IgG4 positive rate was significantly lower than the anti-N protein IgG4 positive rate.

\section{Cytokine Concentrations}

We included ten healthy donors as controls to compare the concentrations of IL-2, IL-4, IL-6, IL-10, CCL2, CXCL10, IFN- $\gamma$, and TNF- $\alpha$ between moderate and severe patients in Figure 5. Through the Mann-Whitney test, we found that only the average concentrations of IL-2 were higher in healthy controls than in COVID-19 patients $(P<0.001)$. In both moderate and severe COVID-19 patients, the average concentrations of IL-4, IL-6, IL-10, CCL2, IFN- $\gamma$, and TNF- $\alpha(P<0.05)$ were higher than those in healthy donors. Among them, IL-6 in severe patients was significantly higher than that in moderate patients. There was no relationship between cytokines and neutralizing antibodies, as determined by Spearman analysis.

\section{DISCUSSION}

In this study, we characterized the antibody and cytokine responses in COVID-19 patients. The proportion of patients with a history of disease in moderate and severe patients is more
A

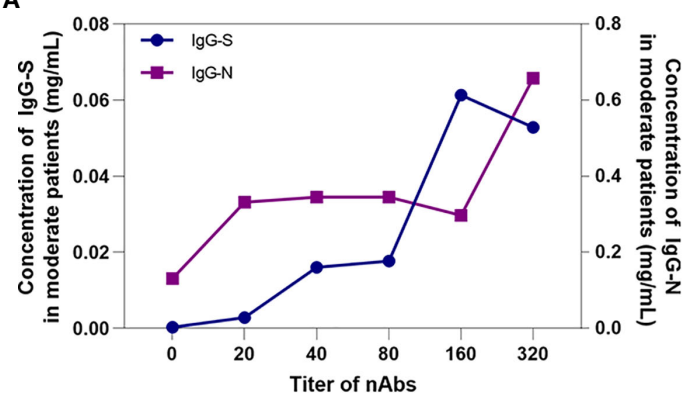

C

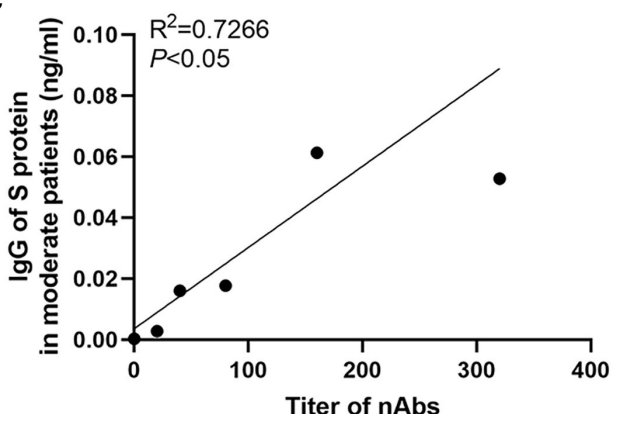

B

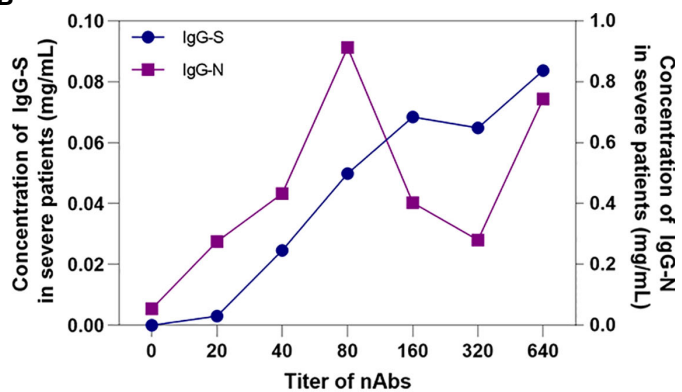

D

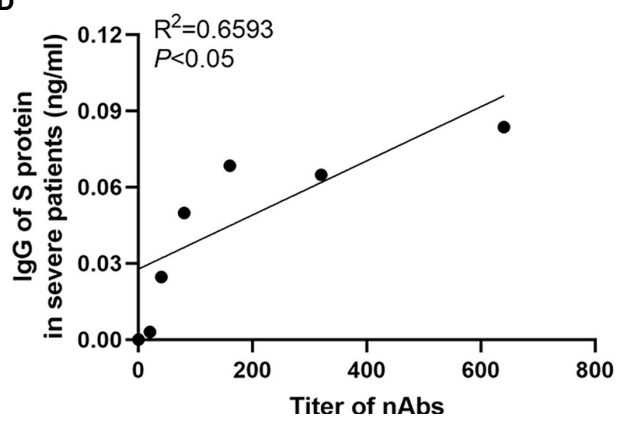

FIGURE 3 | The correlation between antibodies. The relationship between lgG-S and IgG-N antibody levels and nAb titers in moderate patients (A) and severe patients (B). The correlation between IgG-S antibody levels and nAb titers in moderate patients (C) and severe patients (D). 
A

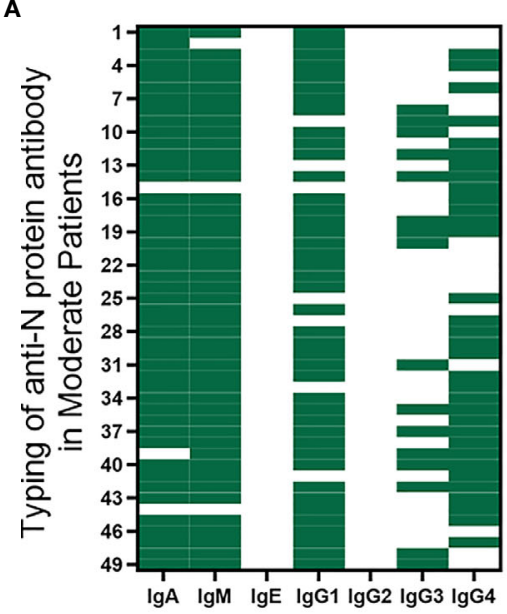

。

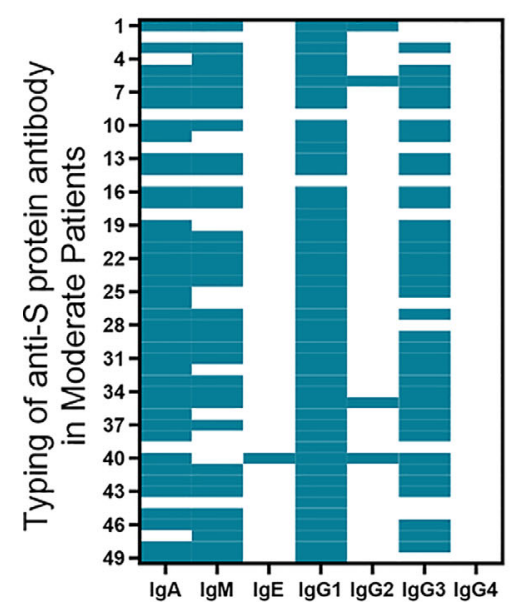

1.0

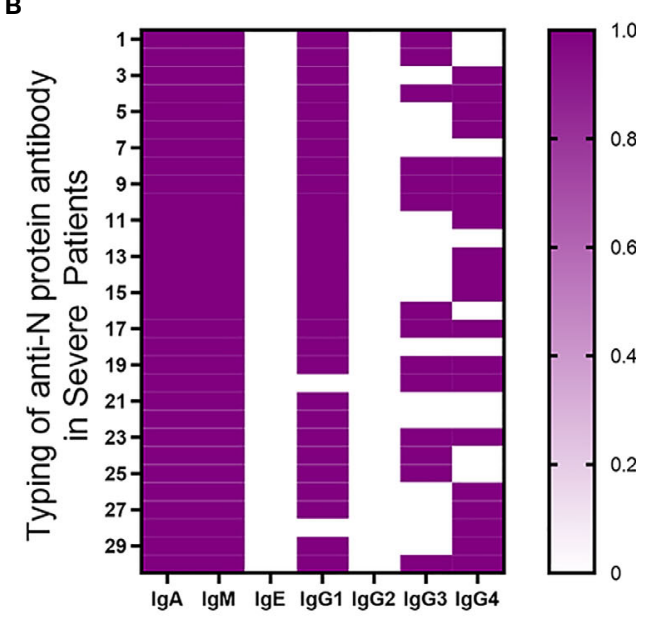

D
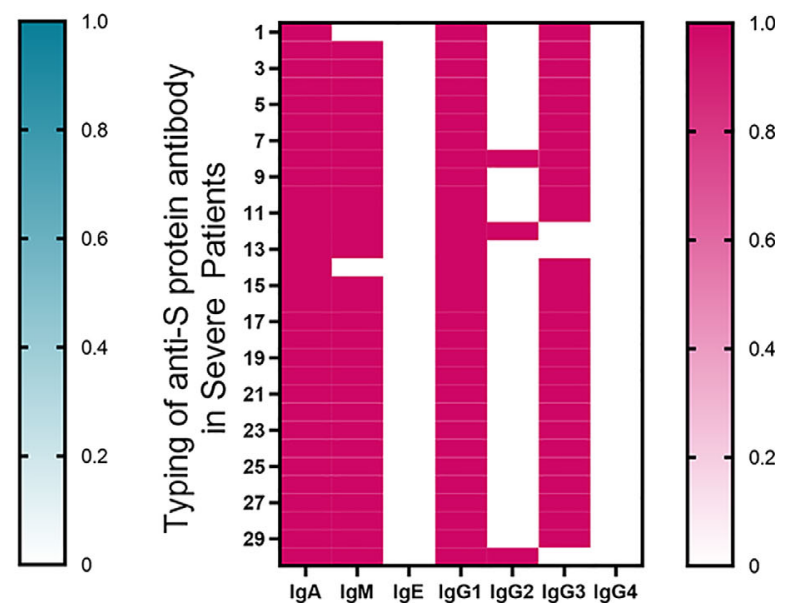

FIGURE 4 | Classification of anti-S protein and anti-N protein antibodies. (A, B) The typing of anti-N protein immunoglobulin in moderate and severe patients. (C, D) The typing of anti-S protein immunoglobulin in moderate and severe patients. Samples with a fluorescence value greater than 0.2 were regarded as positive, with an assignment of 1 ; otherwise, they were regarded as negative, with an assignment of 0 .

than $50 \%$, which may accelerate the disease process of patients with COVID-19 (53, 54).

The average neutralizing antibody titer and IgG-S of severe patients were significantly higher than those of moderate patients. Neutralizing antibodies can block viral infection and have a good therapeutic effect on patients with COVID-19 (1418). Recent research found that higher viral loads and stronger antibody responses are related to more severe disease status in patients with SARS-CoV-2 infection $(21,55)$. These results suggest that patients with more severe clinical typing may have a stronger immunity to the virus (56). It is worth noting that the later stage of severe patients is not caused by SARS-CoV-2 but may be caused by their own immune damage.

From our quantitative data, we confirmed the conclusion of previous studies that PCR positive time is related to antibody concentration (57), and we found that the IgG-N concentration was higher than the IgG-S concentration $(P<0.0001)$, not only because the nucleoprotein released by SARS-CoV-2 is more abundant than the spike protein but also because the spike protein has structural changes between prefusion and postfusion (58). Most of the antibodies produced by the innate immune system target the postfusion spike protein, which causes the body to overreact and produce an antibodydependent enhancement effect (ADE) (59). In addition, most of the immune responses activated by SARS-CoV-2-infected humans produce IgG-N with no neutralizing activity in the early phase after symptom onset (60), which is also difficult in the development of neutralizing antibodies and vaccines. Additionally, we compared the neutralizing antibodies, IgG-N antibodies, and IgG-S antibodies of COVID-19 patients with different clinical symptoms. There is a positive correlation between the nAbs and IgG-S antibodies, due to the existence of sites on the $S$ protein that bind to multiple receptors of target cells (61-63).

The positive detection rate of IgA and IgM in COVID-19 infection was related to the positive detection time of PCR and 

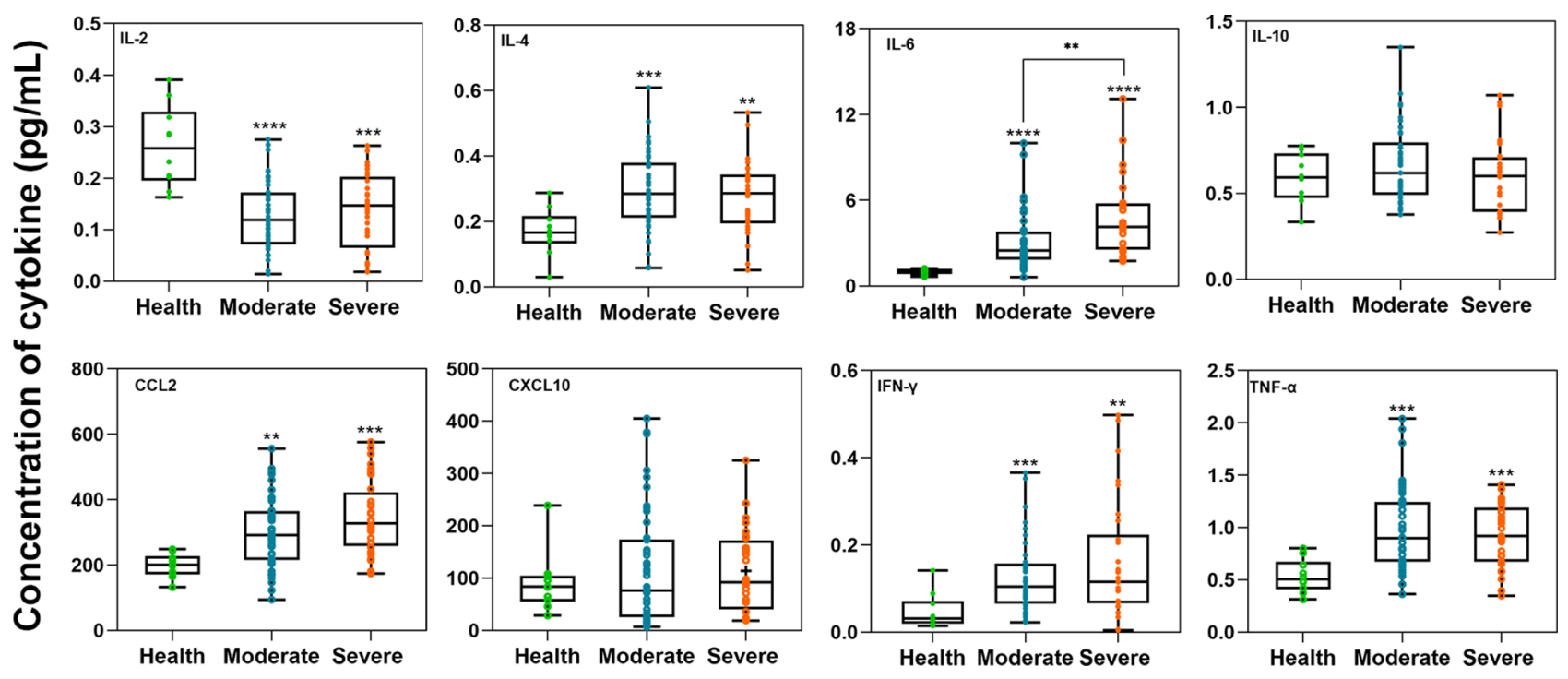

FIGURE 5 | The comparison of cytokine concentrations between the healthy donor and moderate or severe groups. The unit of the eight cytokine concentrations was $\mathrm{pg} / \mathrm{mL}$. The box plots show the medians (middle line) and first and third quartiles (boxes), and the whiskers show the minimum and maximum. Mann-Whitney test $P$-values are depicted in the plots. I bars indicate standard deviations. ${ }^{* \star} \mathrm{p}<0.01,{ }^{* \star *} \mathrm{p}<0.001,{ }^{\star \star \star *} \mathrm{p}<0.0001$.

Clinical classification. In the early stage of infection, with the increase of infection time, the detection rate of antibody was higher $(22,64,65)$. The positive rates of anti-N protein IgA and IgM antibodies were higher than anti-S protein, which was similarly related to the structure of SARS-CoV-2 mentioned above. Secretory IgA (SIgA) is the main component of the mucosal defense system. The content of SIgA in respiratory secretions directly affects the resistance of respiratory mucosa to pathogens, and there is a positive correlation between them (66). Although the role of serum IgA is relatively unexplored, it can transmit activating signals, leading to phagocytosis, respiratory burst, ADCC, increased antigen presentation, degranulation and cytokine release (67-69). Upregulated IgA production may be the result of increased levels of TGF- $\beta$ and IL-10, which promote antibody switching in SARS-CoV-2 infection $(70,71)$.

The first line of defense for severe patients to prevent pathogens from invading the body is stronger. Among anti-N and anti-S protein antibodies, IgG1 is the most common IgG subclass, and the anti-S protein IgG3 positive rate is significantly higher than the anti- $\mathrm{N}$ protein IgG3 positive rate. IgG3 and IgG1 exhibit the most efficient activation of the classical complement cascade, but IgG4 generally cannot activate this cascade (72). Therefore, the S protein of SARS-CoV-2 is more likely to trigger effector functions, including complement activation, antibodymediated phagocytosis, or Ab-mediated cellular cytotoxicity (ADCC) (73). The $\mathrm{N}$ protein of SARS-CoV-2 is a chronic antigen that stimulates the production of most terminal IgG4 subclasses (72).

Six cytokines in COVID-19 patients show differences from those in healthy individuals, but they were not related to the antibody titer. IFN- $\gamma$, TNF- $\alpha$, and IL-2 are the main inflammatory factors of Th1 cytokines and can induce pathogenesis. Similar to previous research, IFN- $\gamma$ and TNF- $\alpha$ are significantly higher in COVID-19 patients than in healthy individuals. However, in contrast to previous studies, our data show that the concentration of IL-2 in COVID-19 patients is significantly lower than that in healthy individuals $(48,74-77)$. This difference may be related to sample sources and clinical treatment, which suggests that cytokine storms are different in different populations even infected with the same pathogen. Th2 cytokines, including IL-4, IL-6, and IL-10, have anti-inflammatory effects and can prevent pathogenesis and alleviate diseases. IL-4, as a part of the cytokine storm associated with severe respiratory symptoms, is significantly higher in COVID-19 patients than in healthy individuals $(74,78)$. Our study found that IL-6 is related not only to the severity of SARS symptoms but also to SARS-CoV2 infection $(79,80)$. The proinflammatory chemokine CCL2 can mediate the directional migration of immune cells and is also higher in COVID-19 patients than in healthy individuals (81). The data show that severe clinical symptoms are closely related to the joint action of a variety of cytokines (44, 82-84).

\section{CONCLUSION}

In summary, the nAbs and IgG-S in severe patients were significantly higher than those in moderate patients, and the two antibodies had a positive correlation. There was a difference in immunoglobulin type between anti-S protein antibody and anti-N protein antibody in COVID-19 patients. Anti-S protein IgG3 was significantly more abundant than anti-N protein IgG3, while anti-N protein IgG4 was significantly more abundant than anti-S IgG4. Many cytokines in COVID-19 patients were significantly different from those in healthy individuals, 
including IL-2, IL-4, IL-6, CCL2, IFN- $\gamma$, and TNF- $\alpha$. There was no relationship between cytokines and neutralizing antibodies. The different immune characteristics of COVID-19 patients with different clinical types were significant for the systematic study of the pathogenic mechanism of SARS-CoV-2.

\section{DATA AVAILABILITY STATEMENT}

The original contributions presented in the study are included in the article/Supplementary Material. Further inquiries can be directed to the corresponding authors.

\section{ETHICS STATEMENT}

The studies involving human participants were reviewed and approved by Beijing Youan Hospital Research Ethics Committee (No. 2020-037). The patients/participants provided their written informed consent to participate in this study.

\section{AUTHOR CONTRIBUTIONS}

TL, YL, and LL contributed to conception and design of the study. XX, BS, and YF contributed to sample collection. YG contributed to organized the database, performed the statistical analysis, wrote the first draft of the manuscript. HL, JH, and XW

\section{REFERENCES}

1. Yang X, Yu Y, Xu J, Shu H, Xia JA, Liu H, et al. Clinical Course and Outcomes of Critically Ill Patients With SARS-CoV-2 Pneumonia in Wuhan, China: A Single-Centered, Retrospective, Observational Study. Lancet Respir Med (2020) 8(5):475-81. doi: 10.1016/S2213-2600(20)30079-5

2. Li Y, Hou G, Zhou H, Wang Y, Tun HM, Zhu A, et al. Multi-Platform Omics Analysis Reveals Molecular Signature for COVID-19 Pathogenesis, Prognosis and Drug Target Discovery. Signal Transduct Target Ther (2021) 6(1):155. doi: 10.1038/s41392-021-00508-4

3. Wu Z, McGoogan JM. Characteristics of and Important Lessons From the Coronavirus Disease 2019 (COVID-19) Outbreak in China: Summary of a Report of 72314 Cases From the Chinese Center for Disease Control and Prevention. JAMA (2020) 323(13):1239-42. doi: 10.1001/jama.2020.2648

4. Yuchun N, Guangwen W, Xuanling S, Hong Z, Yan Q, Zhongping H, et al. Neutralizing Antibodies in Patients With Severe Acute Respiratory Syndrome-Associated Coronavirus Infection. J Infect Dis (2004) 190 (6):1119-26. doi: 10.1086/423286

5. Zhang B, Liu S, Tan T, Huang W, Dong Y, Chen L, et al. Treatment With Convalescent Plasma for Critically Ill Patients With Severe Acute Respiratory Syndrome Coronavirus 2 Infection. Chest (2020) 158(1):e9-e13. doi: 10.1016/ j.chest.2020.03.039

6. Amanat F, Stadlbauer D, Strohmeier S, Nguyen THO, Chromikova V, McMahon $\mathrm{M}$, et al. A Serological Assay to Detect SARS-CoV-2 Seroconversion in Humans. Nat Med (2020) 26(7):1033-6. doi: 10.1038/s41591-020-0913-5

7. Grzelak L, Temmam S, Planchais C, Demeret C, Tondeur L, Huon C, et al. A Comparison of Four Serological Assays for Detecting Anti-SARS-CoV-2 Antibodies in Human Serum Samples From Different Populations. Sci Trans Med (2020) 12(559):eabc3103. doi: 10.1126/scitranslmed.abc3103

8. He Y, Luo J, Yang J, Song J, Wei L, Ma W. Value of Viral Nucleic Acid in Sputum and Feces and Specific IgM/IgG in Serum for the Diagnosis of contributed to bibliographic survey. LJ, ZB, and JL were involved in the critical revision of the article. All authors contributed to the article and approved the submitted version.

\section{FUNDING}

Supported by the key special project of "Technology for Economy 2020" of Beijing Municipal Commission of Science and Technology, the Emergency Key Program of Guangzhou Laboratory (Grant No. EKPG21-01), the National Natural Science Foundation of China $(81772165,81974303$ to BS), and the China Primary Health Care Foundation-Youan Medical Development Fund (BJYAYY-2020PY-01 to BS).

\section{ACKNOWLEDGMENTS}

We thank Beijing KEWEI Clinical Diagnostic Reagent Inc. for providing IgG antibodies against SARS-CoV-2 spike protein and nucleoprotein ELISA kits and ELISA readers.

\section{SUPPLEMENTARY MATERIAL}

The Supplementary Material for this article can be found online at: https://www.frontiersin.org/articles/10.3389/fimmu.2021. 723585/full\#supplementary-material

Coronavirus Disease 2019. Front Cell infect Microbiol (2020) 10:445 doi: $10.3389 /$ fcimb. 2020.00445

9. Brochot E, Demey B, Touzé A, Belouzard S, Dubuisson J, Schmit J-L, et al. Anti-Spike, Anti-Nucleocapsid and Neutralizing Antibodies in SARS-CoV-2 Inpatients and Asymptomatic Individuals. Front Microbiol (2020) 11:584251. doi: $10.3389 /$ fmicb.2020.584251

10. Sterlin D, Mathian A, Miyara M, Mohr A, Anna F, Claër L, et al. IgA Dominates the Early Neutralizing Antibody Response to SARS-CoV-2. Sci Trans Med (2021) 13(577):eabd2223. doi: 10.1126/scitranslmed.abd2223

11. Zhao J, Yuan Q, Wang H, Liu W, Liao X, Su Y, et al. Antibody Responses to SARS-CoV-2 in Patients With Novel Coronavirus Disease 2019. Clin Infect Dis an Off Publ Infect Dis Soc America (2020) 71(16):2027-34. doi: 10.1093/ cid/ciaa344

12. Luo H, Jia T, Chen J, Zeng S, Qiu Z, Wu S, et al. The Characterization of Disease Severity Associated IgG Subclasses Response in COVID-19 Patients. Front Immunol (2021) 12:632814. doi: 10.3389/fimmu.2021.632814

13. Pritchard DI, Falcone FH, Mitchell PD. The Evolution of IgE-Mediated Type I Hypersensitivity and its Immunological Value. Allergy (2021) 76(4):1024-40. doi: 10.1111/all.14570

14. Zhou P, Yang XL, Wang XG, Hu B, Zhang L, Zhang W, et al. A Pneumonia Outbreak Associated With a New Coronavirus of Probable Bat Origin. Nature (2020) 579(7798):270-3. doi: 10.1038/s41586-020-2012-7

15. Ju B, Zhang Q, Ge J, Wang R, Sun J, Ge X, et al. Human Neutralizing Antibodies Elicited by SARS-CoV-2 Infection. Nature (2020) 584(7819):1159. doi: 10.1038/s41586-020-2380-Z

16. Wu Y, Wang F, Shen C, Peng W, Li D, Zhao C, et al. A Noncompeting Pair of Human Neutralizing Antibodies Block COVID-19 Virus Binding to Its Receptor ACE2. Science (2020) 368(6496):1274-8. doi: 10.1126/science.abc2241

17. Shi R, Shan C, Duan X, Chen Z, Liu P, Song J, et al. A Human Neutralizing Antibody Targets the Receptor Binding Site of SARS-CoV-2. Nature (2020) 584(7819):120-4. doi: 10.1038/s41586-020-2381-y 
18. Cerutti G, Guo Y, Zhou T, Gorman J, Lee M, Rapp M, et al: Potent SARSCoV-2 Neutralizing Antibodies Directed Against Spike N-Terminal Domain Target a Single Supersite. Cell Host Microbe (2021) 29(5):819-33.e7. doi: 10.1016/j.chom.2021.03.005

19. Cao Y, Su B, Guo X, Sun W, Deng Y, Bao L, et al. Potent Neutralizing Antibodies Against SARS-CoV-2 Identified by High-Throughput Single-Cell Sequencing of Convalescent Patients' B Cells. Cell (2020) 182(1):73-84.e16. doi: 10.1016/j.cell.2020.05.025

20. Wajnberg A, Amanat F, Firpo A, Altman DR, Bailey MJ, Mansour M, et al. Robust Neutralizing Antibodies to SARS-CoV-2 Infection Persist for Months. Sci (New York N.Y.) (2020) 370(6521):1227-30. doi: 10.1126/science.abd7728

21. Wang Y, Zhang L, Sang L, Ye F, Ruan S, Zhong B, et al. Kinetics of Viral Load and Antibody Response in Relation to COVID-19 Severity. J Clin Invest (2020) 130(10):5235-44. doi: 10.1172/JCI138759

22. Zhao J, Yuan Q, Wang H, Liu W, Liao X, Su Y, et al. Antibody Responses to SARS-CoV-2 in Patients With Novel Coronavirus Disease 2019. Clin Infect Dis (2020) 71(16):2027-34. doi: 10.1093/cid/ciaa344

23. Ma H, Zeng $W$, He H, Zhao D, Jiang D, Zhou $P$, et al. Serum IgA, IgM, and IgG Responses in COVID-19. Cell Mol Immunol (2020) 17(7):773-5. doi: 10.1038/s41423-020-0474-Z

24. Seow J, Graham C, Merrick B, Acors S, Pickering S, Steel KJA, et al. Longitudinal Observation and Decline of Neutralizing Antibody Responses in the Three Months Following SARS-CoV-2 Infection in Humans. Nat Microbiol (2020) 5(12):1598-607. doi: 10.1038/s41564-020-00813-8

25. Okba NMA, Müller MA, Li W, Wang C, GeurtsvanKessel CH, Corman VM, et al. Severe Acute Respiratory Syndrome Coronavirus 2-Specific Antibody Responses in Coronavirus Disease Patients. Emerging Infect Dis (2020) 26 (7):1478-88. doi: 10.3201/eid2607.200841

26. Huang C, Wang Y, Li X, Ren L, Zhao J, Hu Y, et al. Clinical Features of Patients Infected With 2019 Novel Coronavirus in Wuhan, China. Lancet (London England) (2020) 395(10223):497-506. doi: 10.1016/S0140-6736(20) 30183-5

27. Lucas C, Wong P, Klein J, Castro TBR, Silva J, Sundaram M, et al. Longitudinal Analyses Reveal Immunological Misfiring in Severe COVID19. Nature (2020) 584(7821):463-9. doi: 10.1038/s41586-020-2588-y

28. Mier JW, Gallo RC. Purification and Some Characteristics of Human T-Cell Growth Factor From Phytohemagglutinin-Stimulated LymphocyteConditioned Media. Proc Natl Acad Sci USA (1980) 77(10):6134-8. doi: 10.1073/pnas.77.10.6134

29. Malek TR, Bayer AL. Tolerance, Not Immunity, Crucially Depends on IL-2. Nature Reviews. Immunology (2004) 4(9):665-74. doi: 10.1038/nri1435

30. Noval Rivas M, Burton OT, Oettgen HC, Chatila T. IL-4 Production by Group 2 Innate Lymphoid Cells Promotes Food Allergy by Blocking Regulatory TCell Function. J Allergy Clin Immunol (2016) 138(3):801-11.e9. doi: 10.1016/ j.jaci.2016.02.030

31. Li Z, Chen L, Qin Z. Paradoxical Roles of IL-4 in Tumor Immunity. Cell Mol Immunol (2009) 6(6):415-22. doi: 10.1038/cmi.2009.53

32. Celik MÖ., Labuz D, Keye J, Glauben R, Machelska H. IL-4 Induces M2 Macrophages to Produce Sustained Analgesia via Opioids. JCI Insight (2020) 5 (4):e133093. doi: 10.1172/jci.insight.133093

33. Taus F, Salvagno G, Canè S, Fava C, Mazzaferri F, Carrara E, et al. Platelets Promote Thromboinflammation in SARS-CoV-2 Pneumonia. Arteriosclerosis thrombosis Vasc Biol (2020) 40(12):2975-89. doi: 10.1161/ATVBAHA.120.315175

34. Jirik FR, Podor TJ, Hirano T, Kishimoto T, Loskutoff DJ, Carson DA, et al. Bacterial Lipopolysaccharide and Inflammatory Mediators Augment IL-6 Secretion by Human Endothelial Cells. J Immunol (Baltimore Md. 1950) (1989) 142(1):144-7.

35. Laudes IJ, Chu JC, Huber-Lang M, Guo R-F, Riedemann NC, Sarma JV, et al. Expression and Function of C5a Receptor in Mouse Microvascular Endothelial Cells. J Immunol (Baltimore Md. 1950) (2002) 169(10):5962-70. doi: 10.4049/jimmunol.169.10.5962

36. Carter MJ, Fish M, Jennings A, Doores KJ, Wellman P, Seow J, et al. Peripheral Immunophenotypes in Children With Multisystem Inflammatory Syndrome Associated With SARS-CoV-2 Infection. Nat Med (2020) 26(11):1701-7. doi: 10.1038/s41591-020-1054-6

37. Saraiva M, Vieira P, O'Garra A. Biology and Therapeutic Potential of Interleukin-10. J Exp Med (2020) 217(1):e20190418. doi: 10.1084/ jem.20190418
38. Ouyang W, Rutz S, Crellin NK, Valdez PA, Hymowitz SG. Regulation and Functions of the IL-10 Family of Cytokines in Inflammation and Disease. Annu Rev Immunol (2011) 29:71-109. doi: 10.1146/annurev-immunol031210-101312

39. Saraiva M, O'Garra A. The Regulation of IL-10 Production by Immune Cells. Nat Rev Immunol (2010) 10(3):170-81. doi: 10.1038/nri2711

40. Blot M, Jacquier M, Aho Glele L-S, Beltramo G, Nguyen M, Bonniaud P, et al. CXCL10 Could Drive Longer Duration of Mechanical Ventilation During COVID-19 ARDS. Crit Care (London England) (2020) 24(1):632. doi: 10.1186/s13054-020-03328-0

41. Xiong Y, Liu Y, Cao L, Wang D, Guo M, Jiang A, et al. Transcriptomic Characteristics of Bronchoalveolar Lavage Fluid and Peripheral Blood Mononuclear Cells in COVID-19 Patients. Emerging Microbes infect (2020) 9(1):761-70. doi: 10.1080/22221751.2020.1747363

42. Chua RL, Lukassen S, Trump S, Hennig BP, Wendisch D, Pott F, et al. COVID-19 Severity Correlates With Airway Epithelium-Immune Cell Interactions Identified by Single-Cell Analysis. Nat Biotechnol (2020) 38 (8):970-9. doi: 10.1038/s41587-020-0602-4

43. Karki R, Sharma BR, Tuladhar S, Williams EP, Zalduondo L, Samir P, et al. Synergism of TNF- $\alpha$ and IFN- $\gamma$ Triggers Inflammatory Cell Death, Tissue Damage, and Mortality in SARS-CoV-2 Infection and Cytokine Shock Syndromes. Cell (2021) 184(1):149-68.e17. doi: 10.1016/j.cell.2020.11.025

44. Huang C, Wang Y, Li X, Ren L, Zhao J, Hu Y, et al. Clinical Features of Patients Infected With 2019 Novel Coronavirus in Wuhan, China. Lancet (2020) 395(10223):497-506. doi: 10.1016/s0140-6736(20)30183-5

45. Moore JB, June CH. Cytokine Release Syndrome in Severe COVID-19. Sci (New York N.Y.) (2020) 368(6490):473-4. doi: 10.1126/science.abb8925

46. Tan M, Liu Y, Zhou R, Deng X, Li F, Liang K, et al. Immunopathological Characteristics of Coronavirus Disease 2019 Cases in Guangzhou, China. Immunology (2020) 160(3):261-8. doi: 10.1111/imm.13223

47. Diao B, Wang C, Tan Y, Chen X, Liu Y, Ning L, et al. Reduction and Functional Exhaustion of T Cells in Patients With Coronavirus Disease 2019 (COVID-19). Front Immunol (2020) 11:827. doi: 10.3389/fimmu.2020.00827

48. Chen G, Wu D, Guo W, Cao Y, Huang D, Wang H, et al. Clinical and Immunological Features of Severe and Moderate Coronavirus Disease 2019. J Clin Invest (2020) 130(5):2620-9. doi: 10.1172/JCI137244

49. Del Valle DM, Kim-Schulze S, Huang H-H, Beckmann ND, Nirenberg S, Wang B, et al. An Inflammatory Cytokine Signature Predicts COVID-19 Severity and Survival. Nat Med (2020) 26(10):1636-43. doi: 10.1038/s41591020-1051-9

50. Lv Z, Deng YQ, Ye Q, Cao L, Sun CY, Fan C, et al. Structural Basis for Neutralization of SARS-CoV-2 and SARS-CoV by a Potent Therapeutic Antibody. Science (2020) 369(6510):1505-9. doi: 10.1126/science.abc5881

51. Wu HS, Chiu SC, Tseng TC, Lin SF, Lin JH, Hsu YH, et al. Serologic and Molecular Biologic Methods for SARS-Associated Coronavirus Infection, Taiwan. Emerg Infect Dis (2004) 10(2):304-10. doi: 10.3201/eid1002.030731

52. Wajnberg A, Amanat F, Firpo A, Altman DR, Bailey MJ, Mansour M, et al. Robust Neutralizing Antibodies to SARS-CoV-2 Infection Persist for Months. Science (2020) 370(6521):1227-30. doi: 10.1126/science.abd7728

53. Gudbjartsson DF, Norddahl GL, Melsted P, Gunnarsdottir K, Holm H, Eythorsson E, et al. Humoral Immune Response to SARS-CoV-2 in Iceland. $N$ Engl J Med (2020) 383(18):1724-34. doi: 10.1056/NEJMoa2026116

54. Hu X, Hu C, Yang Y, Chen J, Zhong P, Wen Y, et al. Clinical Characteristics and Risk Factors for Severity of COVID-19 Outside Wuhan: A Double-Center Retrospective Cohort Study of 213 Cases in Hunan, China. Ther Adv Respir Dis (2020) 14:1753466620963035. doi: 10.1177/1753466620963035

55. Zhang X, Lu S, Li H, Wang Y, Lu Z, Liu Z, et al. Viral and Antibody Kinetics of COVID-19 Patients With Different Disease Severities in Acute and Convalescent Phases: A 6-Month Follow-Up Study. Virologica Sin (2020) 35 (6):820-9. doi: 10.1007/s12250-020-00329-9

56. Boonyaratanakornkit J, Morishima C, Selke S, Zamora D, McGuffin SA Shapiro AE, et al. Clinical, Laboratory, and Temporal Predictors of Neutralizing Antibodies to SARS-CoV-2 Among COVID-19 Convalescent Plasma Donor Candidates. J Clin Invest (2020) 131(3):e144930. doi: 10.1172/ jci144930

57. Sun B, Feng Y, Mo X, Zheng P, Wang Q, Li P, et al. Kinetics of SARS-CoV-2 Specific IgM and IgG Responses in COVID-19 Patients. Emerging Microbes infect (2020) 9(1):940-8. doi: 10.1080/22221751.2020.1762515 
58. Yao H, Song Y, Chen $\mathrm{Y}, \mathrm{Wu} \mathrm{N}, \mathrm{Xu}$ J, Sun $\mathrm{C}$, et al. Molecular Architecture of the SARS-CoV-2 Virus. Cell (2020) 183(3):730-8.e13. doi: 10.1016/j.cell.2020.09.018

59. Arvin AM, Fink K, Schmid MA, Cathcart A, Spreafico R, Havenar-Daughton C, et al. A Perspective on Potential Antibody-Dependent Enhancement of SARSCoV-2. Nature (2020) 584(7821):353-63. doi: 10.1038/s41586-020-2538-8

60. Hashem AM, Algaissi A, Almahboub SA, Alfaleh MA, Abujamel TS, Alamri SS, et al. Early Humoral Response Correlates With Disease Severity and Outcomes in COVID-19 Patients. Viruses (2020) 12(12):1390. doi: 10.3390/v12121390

61. Gu Y, Cao J, Zhang X, Gao H, Wang Y, Wang J, et al. Interaction Network of SARS-CoV-2 With Host Receptome Through Spike Protein. bioRxiv (2020) 2020:9.09.287508. doi: 10.1101/2020.09.09.287508

62. Premkumar L, Segovia-Chumbez B, Jadi R, Martinez DR, Raut R, Markmann A, et al. The Receptor Binding Domain of the Viral Spike Protein is an Immunodominant and Highly Specific Target of Antibodies in SARS-CoV-2 Patients. Sci Immunol (2020) 5(48):eabc8413. doi: 10.1126/sciimmunol.abc8413

63. Tian X, Liu L, Jiang W, Zhang H, Liu W, Li J. Potent and Persistent Antibody Response in COVID-19 Recovered Patients. Front Immunol (2021) 12:659041. doi: 10.3389/fimmu.2021.659041

64. Suhandynata RT, Hoffman MA, Kelner MJ, McLawhon RW, Reed SL, Fitzgerald RL. Longitudinal Monitoring of SARS-CoV-2 IgM and IgG Seropositivity to Detect COVID-19. J Appl Lab Med (2020) 5(5):908-20. doi: $10.1093 / \mathrm{jalm} / \mathrm{jfaa} 079$

65. Ma H, Zeng W, He H, Zhao D, Jiang D, Zhou P, et al. Serum IgA, IgM, and IgG Responses in COVID-19. Cell Mol Immunol (2020) 17(7):773-5. doi: 10.1038/s41423-020-0474-z

66. Boyaka PN. Inducing Mucosal IgA: A Challenge for Vaccine Adjuvants and Delivery Systems. J Immunol (Baltimore Md. 1950) (2017) 199(1):9-16. doi: $10.4049 /$ jimmunol.1601775

67. Olas K, Butterweck H, Teschner W, Schwarz HP, Reipert B. Immunomodulatory Properties of Human Serum Immunoglobulin A: Anti-Inflammatory and Pro-Inflammatory Activities in Human Monocytes and Peripheral Blood Mononuclear Cells. Clin Exp Immunol (2005) 140 (3):478-90. doi: 10.1111/j.1365-2249.2005.02779.x

68. Leong KW, Ding JL. The Unexplored Roles of Human Serum IgA. DNA Cell Biol (2014) 33(12):823-9. doi: 10.1089/dna.2014.2639

69. Oortwijn BD, Roos A, van der Boog PJM, Klar-Mohamad N, van Remoortere A, Deelder AM, et al. Monomeric and Polymeric IgA Show a Similar Association With the Myeloid FcalphaRI/Cd89. Mol Immunol (2007) 44 (5):966-73. doi: 10.1016/j.molimm.2006.03.014

70. Yu H-Q, Sun B-Q, Fang Z-F, Zhao J-C, Liu X-Y, Li Y-M, et al. Distinct Features of SARS-CoV-2-Specific IgA Response in COVID-19 Patients. Eur Respir J (2020) 56(2):2001526. doi: 10.1183/13993003.01526-2020

71. Dullaers M, Li D, Xue Y, Ni L, Gayet I, Morita R, et al. A T Cell-Dependent Mechanism for the Induction of Human Mucosal Homing Immunoglobulin A-Secreting Plasmablasts. Immunity (2009) 30(1):120-9. doi: 10.1016/ j.immuni.2008.11.008

72. Valenzuela NM, Schaub S. The Biology of IgG Subclasses and Their Clinical Relevance to Transplantation. Transplantation (2018) 102(1S Suppl 1):S7-13. doi: 10.1097/TP.0000000000001816

73. Damelang T, Rogerson SJ, Kent SJ, Chung AW. Role of IgG3 in Infectious Diseases. Trends Immunol (2019) 40(3):197-211. doi: 10.1016/j.it.2019.01.005

74. Huang C, Wang Y, Li X, Ren L, Zhao J, Hu Y, et al. Clinical Features of Patients Infected With 2019 Novel Coronavirus in Wuhan, China. Lancet (2020) 395(10223):497-506. doi: 10.1016/s0140-6736(20)30183-5
75. Liu K, Fang YY, Deng Y, Liu W, Wang MF, Ma JP, et al. Clinical Characteristics of Novel Coronavirus Cases in Tertiary Hospitals in Hubei Province. Chin Med J (Engl) (2020) 133(9):1025-31. doi: 10.1097/cm9.0000000000000744

76. Sattler A, Angermair S, Stockmann H, Heim KM, Khadzhynov D, Treskatsch $\mathrm{S}$, et al. SARS-CoV-2-Specific T Cell Responses and Correlations With COVID-19 Patient Predisposition. J Clin Invest (2020) 130(12):6477-89. doi: $10.1172 / J C I 140965$

77. Du H, Dong X, Zhang J-J, Cao Y-Y, Akdis M, Huang P-Q, et al. Clinical Characteristics of 182 Pediatric COVID-19 Patients With Different Severities and Allergic Status. Allergy (2021) 76(2):510-32. doi: 10.1111/all.14452

78. Chen N, Zhou M, Dong X, Qu J, Gong F, Han Y, et al. Epidemiological and Clinical Characteristics of 99 Cases of 2019 Novel Coronavirus Pneumonia in Wuhan, China: A Descriptive Study. Lancet (2020) 395(10223):507-13. doi: 10.1016/S0140-6736(20)30211-7

79. Cheung CY, Poon LLM, Ng IHY, Luk W, Sia S-F, Wu MHS, et al. Cytokine Responses in Severe Acute Respiratory Syndrome Coronavirus-Infected Macrophages In Vitro: Possible Relevance to Pathogenesis. J Virol (2005) 79 (12):7819-26. doi: 10.1128/JVI.79.12.7819-7826.2005

80. Okabayashi T, Kariwa H, . Yokota S-i, Iki S, Indoh T, Yokosawa N, et al. Cytokine Regulation in SARS Coronavirus Infection Compared to Other Respiratory Virus Infections. J Med Virol (2006) 78(4):417-24. doi: 10.1002/ jmv.20556

81. Yao Z, Zheng Z, Wu K, Junhua Z. Immune Environment Modulation in Pneumonia Patients Caused by Coronavirus: SARS-CoV, MERS-CoV and SARS-CoV-2. Aging (2020) 12(9):7639-51. doi: 10.18632/aging.103101

82. Li Q, Xu W, Li WX, Huang CL, Chen L. Dynamics of Cytokines and Lymphocyte Subsets Associated With the Poor Prognosis of Severe COVID-19. Eur Rev Med Pharmacol Sci (2020) 24(23):12536-44. doi: 10.26355/eurrev_202012_24051

83. Zhao Y, Qin L, Zhang P, Li K, Liang L, Sun J, et al. Longitudinal COVID-19 Profiling Associates IL-1RA and IL-10 With Disease Severity and RANTES With Mild Disease. JCI Insight (2020) 5(13):e139834. doi: 10.1172/ jci.insight. 139834

84. Han H, Ma Q, Li C, Liu R, Zhao L, Wang W, et al. Profiling Serum Cytokines in COVID-19 Patients Reveals IL-6 and IL-10 are Disease Severity Predictors. Emerg Microbes Infect (2020) 9(1):1123-30. doi: 10.1080/22221751.2020.1770129

Conflict of Interest: The authors declare that the research was conducted in the absence of any commercial or financial relationships that could be construed as a potential conflict of interest.

Publisher's Note: All claims expressed in this article are solely those of the authors and do not necessarily represent those of their affiliated organizations, or those of the publisher, the editors and the reviewers. Any product that may be evaluated in this article, or claim that may be made by its manufacturer, is not guaranteed or endorsed by the publisher.

Copyright $\odot 2021$ Guo, Li, Xia, Su, Li, Feng, Han, Wang, Jia, Bao, Li, Liu and Li. This is an open-access article distributed under the terms of the Creative Commons Attribution License (CC BY). The use, distribution or reproduction in other forums is permitted, provided the original author(s) and the copyright owner(s) are credited and that the original publication in this journal is cited, in accordance with accepted academic practice. No use, distribution or reproduction is permitted which does not comply with these terms. 